Revue d'études américaines. American Studies Journal

Negotiating Meanings of Borderlands in relation to Arabness, Americanness and Muslimness: Mohja Kahf's The Girl in the Tangerine Scarf (2006)

\title{
Dalal Sarnou
}

\section{(2) OpenEdition \\ Journals}

Electronic version

URL: https://journals.openedition.org/transatlantica/10638

DOI: 10.4000/transatlantica.10638

ISSN: $1765-2766$

\section{Publisher}

Association française d'Etudes Américaines (AFEA)

\section{Electronic reference}

Dalal Sarnou, "Negotiating Meanings of Borderlands in relation to Arabness, Americanness and

Muslimness: Mohja Kahf's The Girl in the Tangerine Scarf (2006)", Transatlantica [Online], 2 I 2017, Online since 13 May 2019, connection on 31 January 2023. URL: http://journals.openedition.org/

transatlantica/10638; DOI: https://doi.org/10.4000/transatlantica.10638

This text was automatically generated on 31 January 2023.

\section{c)}

Creative Commons - Attribution-NonCommercial-NoDerivatives 4.0 International - CC BY-NC-ND 4.0

https://creativecommons.org/licenses/by-nc-nd/4.0/ 


\title{
Negotiating Meanings of Borderlands in relation to Arabness, Americanness and Muslimness: Mohja Kahf's The Girl in the Tangerine $\operatorname{Scarf}(2006)$
}

\author{
Dalal Sarnou
}

\section{Introduction}

An interesting rapid increase of literary works produced in English-and other foreign languages like French and German-by Arab diaspora writers has marked the last few decades. These authors are of Arabic descent. Some of them are academics and intellectuals who migrated to Britain and the U.S.A where they decided to write in English for an international audience. Others are British or American writers who are sons and daughters of early twentieth-century first-generation Arab migrants who settled mainly in the U.S.A. For this group of writers, English is a mother tongue, and Arabic is a mother tongue too. In fact, Arab Anglophone literature crosses the borders of divergent literatures and fuses different, at times opposing, literary traditions. Because this literature is spreading worldwide, more attention is now given to understanding how diasporic Arab writers fictionalize what is happening in their countries of origin. In the context of the terrorist attacks in Europe and in the United States, this new interest can be understood as an attempt to understand the "Other" who, as a Muslim and/or Arab, arguably "threatens" the Western world.

Anglophone Arab diasporic literature is certainly not new; this literature dates back to the turn of the twentieth century when the first Arabs to migrate to the United States had to grapple with the language and culture of the host country. It was in America that an Anglo-Arab literary tradition emerged, with works by Khalil Gibran, Ameen 
Rihani, Abraham Mirtie Rihany and others who were nearly all originally from Mashreq (the Middle East) countries, from Lebanon in particular, and who were far better known for their works in Arabic (Hassan 38). However, except for Gibran, Rihani and Mikhail Naimy, very few writers were known to average American and Western readers at that time.

Current criticism insists that the particularity of Anglophone Arab literature lies in the exceptional fusion of cultural features and linguistic elements of two divergent worlds: the Arab world and the Western world. Several critics (Al Maleh; Nash; Sarnou) argue that the specificity of these works is due to the fact that they are all produced by writers who feel displaced, though in different ways, and always in the contact zone between multiple cultures. As suggested by Geoffrey Nash in The Anglo-Arab Encounter: Fiction and Autobiography by Arab Writers in English, contemporary Anglophone Arab writers use English rather than Arabic as the language of their fiction either because of personal preference, or to avoid cultural restriction and censorship, or else to optimize exposure. Some Anglo-Arab writers were embedded within an English-speaking environment either in their country of origin or in Britain and the United States, and this made English virtually a native language for them. Others, especially those for whom Arabic is their first language but who acquired English through the medium of education at a relatively late stage, are aware that writing in English will imply both losses and gains, acceptance and rejection. Nash argues that whether they write novels in Arabic to be then translated into English or attempt to incorporate Arab meanings into fiction by composing directly in a language that can command a global readership, what these writers produce is bound to be different from what is produced in a local, national context (Arab Voices 14). Though multicolored and distinct, in terms of themes and literary discourse, works by Anglophone Arab writers have contributed to the emergence of an independent literature that is neither Arabic nor English but both-a hybrid literature.

Anglophone Arab narratives, it should be mentioned, grew out of a different context from Francophone Arab narratives. This difference, I argue, originates in the divergent colonial policy practiced by France and Britain. France favored the principle of cultural adjustment and tried to "Frenchify" its territories by repressing the cultural specificity of dominated peoples. Britain eschewed such assimilation, due to the assumption that Arabs and other colonized peoples could never be part of the British cultural fabric (Almaleh 2009). As a matter of fact, Arab francophone literature is generally produced by writers whose sole written language is French and who are only familiar with colloquial-not standard-Arabic. On the other hand, Arab Anglophone literature is produced by writers who are generally well-acquainted with standard Arabic and who have other reasons to write in English, such as having grown up in areas, or having studied in institutions, dominated by English or simply having migrated to Englishspeaking countries. This is the case of Egyptian writer Ahdaf Soueif, Syrian author Mohja Kahf, Palestinian journalist Soraya Antonius, Sudanese novelist Leila Aboulela, and Jordanian novelist Fadia Faqir, among other writers who have recently received recognition worldwide.

Anglophone Arab writers of the diasporas, mainly women authors, are highly conscious of historically established modes of representing Arab and Muslim women. Literary critic Rebecca Hillauer points out that the women covered in her Encyclopedia of Arab Women Filmmakers (2005) are exceptional in their societies. Their observations seldom 
only originate in what I call a gaze from within; they have been shaped by higher education or experiences of living abroad for years, and frequently also by an upbringing in a privileged social class (4). This gaze from within localizes them in a particular zone that is bordered by their Arabness, sometimes Islamness, and often womanness. This zone, as I will show in the next sections, becomes their borderland(s).

\section{Writing from/on the Border: Concepts and Contexts}

Writing from the border, or border writing, has become one of the most appealing literary genres that contemporary critics are theorizing and (re-)conceptualizing. Emily Hicks (1991) states that border writings are to be considered as universal literature.

What makes border writing a world literature with a "universal" appeal is its emphasis upon the multiplicity of languages within any single language; by choosing a strategy of translation rather than representation, border writers ultimately undermine the distinction between original and alien culture. (Hicks xxiii)

Hicks calls for a re-thinking of the concepts of border and borderlands and their correlates such as boundaries, frontiers, barriers, margins and liminal spaces. These concepts have garnered attention in the last few years thanks to the Mexican-American theorist Gloria Anzaldùa. In her seminal book Borderlands/La Frontera (1987), she insists on the semantic and ideological difference between the two concepts of border and borderland. She explains: "a border is a dividing line, a narrow strip along a steep edge. A borderland is a vague and undetermined place created by the emotional residue of an unnatural boundary" (3).

"I am a border woman," Anzaldùa states in the preface to Borderlands: La Frontera (ii). This declaration starts a new journey into the border-zone and initiates a reflection on how people who live on borders, be they physical, geographical or emotional, view the other from within the border-zone space. As Anzaldùa points out, the image of the border has become fully meaningful not only when we consider it as a physical line, but when we de-center and liberate it from the notion of space to encompass notions of sex, class, gender, ethnicity, identity, community, and even language. Taken as a linguistic phenomenon, border-crossing manifests itself as code-switching and codemixing. Shifting from one language to another also means shifting from one culture to another, from one linguistic territory to another, and from one sound system to another, particularly for languages that are widely distinct, as is the case of English vs. Arabic or French vs. Arabic. In that sense, crossing the border does not mean that a physical body steps into a "protected" (other) national space, it is a constant and potentially creative encounter where differences meet and interact. In fact, border crossing invites us to think of a borderland as that which both relates and separates two spaces. Following Anzaldùa, I contend that borders engender border zones or those liminal spaces which allow for mestizaje ${ }^{1}$ and racial and cultural hybridization. However thin and demarcated the line is, it requires its own negation, i.e. the borderlands. Evidently, multiple ways of communication result from these exchanges across the border. 
Next to "borderland," Mary Louise Pratt has theorized the concept of "contact zones," which proves illuminating when one focuses on dialogues on the two sides of the border:

I use the term to refer to social spaces where cultures meet, clash and grapple with each other often in contexts of highly asymmetrical relations of power, such as colonialism, slavery, or their aftermaths as they are lived out in many parts of the world today. (Pratt 17)

What Pratt adds here is the social dimension of "borderlands" as contact zones. And the concept is again complicated in Carolyn Porter's essay "What We Know that We Don't Know: Remapping American Literary Studies" (1994), in which Porter amplifies the range of contact zones through the term "cultural force fields," thereby addressing a wider series of transcultural axes and exchanges, in particular, integrating non-native literatures.

Borders, therefore, are situated neither at the periphery nor at the margins but rather at the core. This becomes evident when dealing with issues of security, not only because after the 9/11 attacks borders became increasingly regarded as a line of defense that needs to be constantly monitored and secured, but because, as a structure, the nation-form produces and perpetuates a differentiation that must be defended (Balibar 23). An interesting and relevant example might be president Donald Trump's border policy, which seeks to secure the U.S. borders with Mexico on the one hand and control who moves into the United States from countries assumed to be the cradle of Islamic Terrorism, on the other hand. Building a wall along the Mexican-American borders and banning people coming from six Muslim countries allow Trump to situate Arab Americans, Mexican Americans and Muslims of America in a particular borderland zone that is both physical and psychological.

To go back to Arab Anglophone narratives, and especially women narratives, the borderlands they display are of different kinds. Some of these writers attempt to represent what I refer to as a social borderland, particularly Arab women writers who have travelled abroad and now belong to two worlds-as is the case with Ahdaf Soueif, Leila Abulela, Laila Alalami, Sabiha Elkhemir, and Mohja Kahf, among others. To cross the borders of their countries of origin means stepping away from patriarchal boundaries and being able to become acknowledged writers. Their border is also cultural since these women have developed a vision from a marginal position inbetween two cultures that have long been opposing entities. Crossing the border of Arab culture to integrate into Western culture is one of the fundamental transnational and cross-cultural characteristics of narratives produced by Anglophone Arab women. The border for Arab women writers of the diasporas is also intellectual. Crossing a rigid ideological boundary imposed by undemocratic political systems-those of the countries in the Middle East and North African (MENA) region since the independence -allows them to develop a new view of the political scene in that region. The Egyptian/ British novelist and commentator Ahdaf Soueif is a good illustration: she has been defending democratic Egypt both under the Muslim Brotherhood rule and now under the military rule of the country. Her political awareness has emerged after crossing the home-country's borders in the 1970s to live in a different cultural and political context -that of the British nation. Soueif, I suggest, has developed a new philosophy that is both liberal and Arab Islamic. She supported young rebels in Tahrir quarter in 2011 and she was also against the massive killing of the Brothers. She expressed her discontent 
when hundreds of protesters were attacked by police in Rabea quarter in 2013. (YassinKassab)

In fact, the threshold for Arab Anglophone women writers might be the English language itself. The English language can be regarded as the vehicle through which women authors of Arabic descent carry a female view of a world that is Western and another that is Arab. The English these authors use in their fiction may represent a borderland where they roam freely to speak their minds without being afraid of any cultural restraint, and therefore this language gives them the power to speak to the world regardless of any language or cultural border issue. This threshold allows these writers to reach further borders and audiences. It is a space of liminality as understood by Manuel Aguirre who defines liminality as that condition ascribed to things or persons who occupy or find themselves in the vicinity of the threshold, either on a permanent basis or as a temporary phenomenon (6-7).

The rest of this essay examines Mohja Kahf's novel The Girl in the Tangerine Scarf, which presents the reader with a new borderland zone occupied by young Arab American Muslim women. The novel can be read, I argue, both as a contact zone where Arabs and Muslims meet other excluded minorities to try and make their struggles converge and a borderland from where these minorities exclude mainstream people, often represented as white Anglo-Saxon protestant.

\section{The Girl in the Tangerine Scarf: On Arabs Living in/ Searching for a Borderland}

Contemporary Anglophone Arab women writings are often read as primarily echoing how Arab women living in the diaspora are caught between a rock and a hard placecaught, that is, between celebrating the hyphen that represents the trans-cultural bridge between the diaspora and the country of origin and being outspoken about the foreign policies embraced by both the West and countries of the MENA region. Accordingly, recent works by Anglophone women writers have given voice to silenced women who have been forced to experience a journey of dislocation and relocation. Miriam Cooke comments:

During the past twenty-five years, women from the Arab world have been writing themselves into visibility at both national and international levels. Historically invisible, they are becoming agents of possible transformations in the societies in which their voices had traditionally not been heard. (Cooke 150)

Mohja Kahf's The Girl in the Tangerine Scarf (2006) belongs to this newly visible group of novels. The main character negotiates her hyphenated identity in the diasporic space through her commitment to an Islam that is neither the one embraced by her parents nor the one fiercely criticized by the West. It is an Islam emerging from a "borderland space," born out of a permanent encounter with a heterogeneous otherness: other people from other cultures, religions and ideologies. In other words, it is an Islam emerging from the very contact zone with other minority groups.

Just like Khadra, the character of the novel, Mohja Kahf was born in Damascus, Syria, in 1971, but just before she turned four, her family migrated to America so that her father could pursue a graduate degree and her mother could finish a Bachelor of Science in Pharmacy. Kahf received her Bachelor of Arts from Rutgers University where she studied Comparative Literature and Political Science and then went on to complete her 
PhD in Comparative Literature in 1988 at the same university. Growing up in the United States, Kahf became aware of Islamophobic sentiments and ignorance. After her family moved to Plainville, Indiana, she experienced painful incidents of racism and oppression. Like other contemporary Arab American authors, Kahf writes of the cultural inequalities faced by Arab Muslims in America focusing thereby on both Muslim vs. Non-Muslim conflict and Muslim to Muslim associations and/or contentions amongst them. Muslims, in America, often find themselves in a hurricane of conflicts that are either based on their religion, culture or even color of skin. They may also find themselves facing each other because of internal religious differences and divergences that split them into various sects and communities: Sunna vs. Shia, Maliki vs. Hanafi, etc. As Susan T. Alkarawi and Ida B. Bahar remark, "her viewpoint disputes hegemonic imageries of Arab-Americans, Muslim women in particular, reviewing mainstream representations of the culture" (102). Kahf writes poems and novels where she fictionalizes racial issues. For her, religion, ethnicity, manner of dress, and simply being different, contributed to the "Arab" becoming a target of America's longstanding racism.

Furthermore, through her narrative, Kahf reflects the heterogeneity within the Muslim and Arab-American community and their negotiation of different patriarchal contexts. The author focuses on Khadra's attempt at re-locating an identity that has been lost between home and diaspora and between a radical Islam and a discriminating secularism. Through her main character and other female relations, Kahf illustrates the heterogeneity in Muslim women's roles and attitudes. She also presents the various challenges that obstruct women's ambitions, because they are faced with cultural patriarchy, western discrimination, religious radicalism and gender-based oppression.

Kahf's novel embodies many borderlands that women belonging to Arab American communities occupy. To fight patriarchy, her female characters find in feminism an empowering border, as is the case with Khadra. Their veils and headscarves (hijab) are themselves a borderland in the sense that it is through this garment that they express their religious determination.

In fact, Kahf's commitment to her Arabness and Islamness has clearly increased since 2011. The author has recently been pre-occupied with the terrifying situation of her home-country, Syria, as much as other American Syrian and British Syrian writers are concerned with the suffering of Syrians back home. In a Facebook message, she says: "thank you, and eid mubarak to you. Syria is not about religious struggle-Syrian Christians, Alawites, Sunnis, Druze, Shias are all in solidarity..." (8/25/2013, 6:18pm Mohja Kahf). Kahf's words reflect her new commitment to Syria as a nation regardless of any kind of schism. Another metamorphosis in Kahf's attitude is the fact that she gave up her headscarf at the beginning of the Syrian uprising. A similar image is to be found in her novel The Girl in the Tangerine Scarf where Khadra also gives up her veil at a given moment in her journey of dislocation/relocation at two different levels: at a micro level, represented by her family and the extremist Islamic approach they embrace, and at a macro level, represented by the larger American community and the racist marginalization of religious and ethnic minorities.

The Girl in the Tangerine Scarf (2006) tells the story of Khadra Shamy's journey of selfdiscovery. Khadra grows up in a strict Muslim community where people are brought up believing in one definition of Islam and rejecting all differences. As the novel progresses, Khadra's perception of her own community, her religion and her identity 
metamorphoses because she goes through different experiences that bring her closer to finding her "true self" as opposed to the identity that she inherits from her parents. Khadra experiences a journey of deterritorialization to a borderland that suits her Americanness, Arabness, womanness and young age.

The story is told by an omniscient narrator who uses flashbacks and flash-forwards. Several of the events in the story take place in Indianapolis, where Khadra "spent most of her growing-up years" (1). Her father had decided to move there in order to work at the Dawah Center, a Muslim community center, where he believed he would answer God's call and help other Muslims. Before that, the first place Khadra lived in the United States was Square One, in the Rocky Mountains. Despite living among American kids, she did not face any kind of discrimination: "The American kids in Square One didn't seem to know yet that they were supposed to be better than the rest because it was their country. Their parents were all students at the same university" (10). However, the sense of un-belonging or belonging-less-ness was soon to come to her as they moved to Indiana. On their first day, when they were still unpacking their belongings, some boys threw glass bottles at their doorstep, and the Shamy family realized they were not welcome. At school, things were not different. She felt that she not only had to face prejudice on the part of other students, but she also had to live with indifference.

Khadra begins with the following lines that immediately recall the difficult journey of re-location in a society that-despite the myth of the melting pot-still rejects minorities and discriminates against ethnic groups:

"Liar," she says to the highway sign that claims "The People of Indiana Welcome You." The olive-skinned, dark-haired young woman drives west on the old National Road. A small zippered Quran and a camera are on the hatchback's passenger seat in easy reach, covered by an open map-States of the Heartland. Khadra Shamy spent most of her growing-up years in Indiana. She knows better than the sign. (Kahf 1)

Kahf's novel undermines the common representation of Muslim women in Western countries. The cover photo of a young lady wearing a tangerine scarf deserves unpacking. The veil that is a symbol of oppression to many Westerners is worn here by a white blond woman. It is widely acknowledged that Muslim women are usually forbidden from wearing clothes with bright colors in the most conservative societies like Saudi Arabia. However, the picture of the Muslim woman on Kahf's cover offers a different representation of the hijab-the girl wears a black T-shirt and blue jeans. Such a cultural and religious blend I identify as "borderland." Kahf, I would argue, offers the Western reader an authentic image of modern Muslim women who indeed are mestizas, having developed hybrid subjectivities of their own. Being a blond white Arab woman, wearing a black T-shirt and blue jeans but also a tangerine headscarf, is the sign of the new mestiza. And this corresponds to modern, intellectual and educated Arab women, whether they live in Western countries or in their Arab home countries. Many headscarved Arab Muslim women indeed are educated, emancipated and determined, but they strongly believe that veiling or unveiling the woman's body is first and foremost a personal choice. One good example is British Sudanese writer Leila Abulela who is herself a vivid representation of these mestizas. She epitomizes hybrid writers who belong to several communities-Aboulela is a Sudanese, Egyptian, Scottish, Muslim, Anglophone and headscarved female. As is suggested by Tiffany Reed (2010), the idea of the veil is starting to change. Women are becoming increasingly 
comfortable with showing their femininity while at the same time asserting their power. They are also showing that they do not have to come from behind their veil to do so.

The Girl in the Tangerine Scarf does just this. By unfolding an Arab-American mestiza's journey in search of an identity, a journey into herself and the Middle East, Khadra tries to come to terms with her Arab and Islam identities as well as her American identity and ends being re-territorialized in a new borderland that is religiously and culturally distinct from her parents'. Khadra does give up wearing the veil by the novel's end, yet she embraces a new persona emerging from the deep strife that she has undergone throughout her childhood and early adult life. Her choice to take off her headscarf may be explained either by the religiously strict life that Khadra' parents and family circle had imposed on her, or by the racist behavior of the outer world she had to confront. Whichever the case, Khadra's decision is that of a new Muslim mestiza who has, at last, found her border zone.

Kahf offers Khadra as an example of a Muslim woman who has created a new identity and a new borderland zone for herself by balancing the two opposite sides of the hyphen so as to be better accepted into mainstream America. By creating such a hyphenated character, Kahf spotlights the conflict between secular and devout Muslims and how they view each other and thereby counters the stereotype of Muslims as brainwashed followers of Islam and terrorists. Khadra is not constrained by a single image of Islam; she has many examples to choose from and emulate as she lives the life she wants-wearing or taking off the headscarf. As is the case for Khadra, Kahf's purpose-her fight-is to free her people from an oppressing regime, to free Arabs and Muslims from a discriminating mainstream culture, and in particular, to rescue women from a patriarchal society.

All through the novel, Khadra is constantly confronted with various images of Muslim women-a heterogeneity within the Muslim community that is often left out from media representations and hegemonic discourse. At the beginning, we are introduced to the image of Khadra's mother, an ambitious educated woman who wanted to go to medical school. She explains to her daughter that she thought she would go to medical school, "But after [she] graduated, [she] chose to stay home. "For the children" (21). Khadra's mother sacrificed her education in order to take care of her children: "I used to dream I would be a doctor one day, and open a free clinic for poor people" (26), she says. Khadra's grandmother, Teta, also embodies the empowered Muslim Arab woman. She was a telephone operator, one of the new jobs that had opened up for women in the old days, and she was among "the very first wave of working women" (271). Teta did not conform to a society that decided that "a telephone girl's job was a bad thing, a thing for loozies." Teta insists on saying "We wanted to be the New Woman" (271).

Khadra's unique perception of important issues like the veil, women rights, and rebellion against any kind of oppression goes back to her extensive travelling from coast to coast, from continent to continent and from country to country. The most significant of these journeys in the novel is her trip to Syria. She visits Syria to "find" herself, believing that a spiritual discovery of her cultural origins will help her shape her own identity without external pressure. In her homeland, she comes to learn things that she never knew, for example how her mother suffered. It is her grandmother who tells her about it. Khadra knew that, after the death of her mother, Ebtehaj, Ebtehaj's stepmother, who was secular, had mistreated her and forced her not to wear the veil 
because she was laughed at for wearing it. At this point we read a different story about the hijab and its impact on Khadra's identity construction, a story that may shock Western readers or surprise them, oppression being equated here with the injunction to take off the veil.

According to Teta, "The city was against it, the tide was against it" (275). Teta tells how "she tried everything-she'd yank it right off her head. I heard she put it in the pot and shat on it" (275) and she was embarrassed to be seen in public with her veiled stepdaughter; she even made Ebtehaj walk on the other side of the street. Ebtehaj's stepmother did not allow her to continue with her Quran circle that she became interested in after her mother's death and tried to force her into marrying a man "who drank and whored, just to make her misery lifelong" (276). Through these stories about her mother's past, Khadra bonds with her grandmother and comes to a better appreciation of her mother.

Eventually, Khadra realizes that her mother was strong enough to hold on to the veil that had caused her so much trouble and was determined to abide by her Islamic beliefs no matter what the trend was at the time. Khadra now is aware that she is not alone in her experiences of dislocation, separation and feeling "betwixt and between." Kahf therefore uses Khadra's journey to Syria to show how women were persecuted for choosing to wear the veil. Khadra hears her aunt tell of the events in Syria in 1982 when the Islamic Front rebelled against a corrupt and dictatorial Syrian government. They seized control of parts of the city of Hama and in response the government launched "a deadly campaign" against the city and its civilians.

Khadra's aunt explains that, in 1982, the capital was blocked by the government and a thousand paratroopers got hold of any woman who was wearing the veil. "You could strip off your hijab [...] or get a gun to your head" (281), she says and adds that her daughter, Reem, on her way home, got stopped by the paratroopers and took off the scarf right away. "Why endanger your life for it?" (281) The paratroopers also asked her to take off her clothes because she was fully covered with her long garb, but she ripped off the scarf "hold[ing] it up in the air and set[ing] it on fire with a blowtorch" (281). But we also get to hear another version of the events, that of Khadra's uncle Mazen, who explains to her that such things happened because of dissidents like Khadra's mother and father who, in his opinion, had politicized the veil and upset the government. Hearing the story of her mother is a shock for Khadra who realizes how momentous her parents' decision to leave their home and migrate to America was; she also comes to realize why her mother sticks to wearing the veil.

Because of what her mother has suffered in a Muslim country, Khadra, then, comes to appreciate the freedom she enjoys in America where she is able to practice her religion without persecution. She may have to deal with the stereotypes and misconceptions; nevertheless, her situation as a practicing Muslim in America is better than that of many in the so-called Muslim countries. In the United States, however, Khadra and her mother face different forms of challenges as the hegemonic culture requires them to hold on to a single allegiance and to let go of any other. Their dilemma lies in the fact that they are coerced into making a firm decision with regards to their identity, and are limited by the two options made available by the dominant culture: either to express their Muslim identity through the veil or assimilate. 


\section{Conclusion}

Kahf's 2006 novel fictionalizes the main challenges faced by Muslim Arab American women when they try both to assimilate into the host culture and preserve their own culture, at the risk of being dislocated in a new zone, a borderland. In fact, Kahf's fiction not only undermines the distorted image of Muslims promoted in America by some local media and more broadly by the foreign policy of the United States, but it also condemns the tyrant regimes that have governed many MENA countries since the independence.

Although in The Girl in the Tangerine Scarf Khadra is presented as an enlightened woman who wears the veil because she believes in what it represents, there are many unpalatable facts about radical Islam and tyrant secular regimes that the character unearths through her journey of displacement. True, she decides to wear the veil in Muslim countries as well as in the United States in spite of the difficulties she faces while wearing it, but the veil is not the focal issue for Khadra as is the case for Kahf: what is worth fighting for in the novel is the freeing of the oppressed and the search for a zone where freedom and tolerance are being celebrated. In this connection, we see Khadra refusing to accommodate herself either to the customs of a Western, secular but discriminative, society or to patriarchal oppression in countries that do not give Muslim women the option to practice freedom of choice. Throughout the novel, Kahf has created a new borderland zone for the Muslim woman who chooses a unique way of living with the Islam that she sees more suitable to her hyphenated identity. It is a zone where religion is an individual choice and not that of a group. The new attitude of Muslim-American women in this novel goes together with the author's new doublevoiced-ness that asserts the right of oppressed people to be heard and liberated. Like most hyphenated Arab writers, Kahf does not give voice to one but many oppressed minorities: immigrants, hyphenated people, Muslims and women.

\section{BIBLIOGRAPHY}

Works cited

AGUIRRE, Manuel, Roberta QUANCE and Phillip C. SUTTON. Margins and Thresholds. An Enquiry into the Concept of Liminality in Text Studies. Madrid: The Gateway Press, 2000.

ALKARAWI, Susan T., and Ida B. BAHAR. "Negotiating Liminal Identities in Mohja Kahf's The Girl in the Tangerine Scarf." International Journal of Applied Linguistics \& English Literature, vol. 2, no. 2, 2013, p. 100-106.

AL MALEH, Layla. Arab Voices in Diaspora: Critical Perspectives on Anglophone Arab Literature. New York: Rodopi, 2009.

ANZALDÚA, Gloria. Borderlands/La Frontera: The New Mestiza. San Francisco: Aunt Lute, 1987. 
ARTEAGA, Alfred. Chicano Poetics: Heterotexts and Hybridities. Cambridge: Cambridge University Press, 1997.

BALIBAR, Etienne. We, the People of Europe? Reflections on Transnational Citizenship. Translated from the French by James Swenson. Princeton, N.J.: Princeton University Press, 2004.

COOKE, Miriam. Women Claim Islam: Creating Islamic Feminism through Literature. London: Routledge, 2001.

HASSAN, Wail. Immigrant Narratives: Orientalism and cultural translation in Arab American and Arab British literature. Oxford: Oxford University press, 2011.

HICKS, D. Emily. Border Writing: The Multidimensional Text. Minneapolis: U. of Minnesota Press, 1991.

HILLAUER, Rebecca. Encyclopedia of Arab Women Filmmakers. Cairo: AUC Press, 2005.

KAHF, Mohja. The Girl in the Tangerine Scarf. New York: Carroll \& Graf, 2006.

NASH, Geoffrey. The Anglo-Arab Encounter: Fiction and Autobiography by Arab Writers in English. Bern: Peter Lang, 2007.

---. "Arab Voices in Western Writing: The Politics of the Arab Novel in English and the Anglophone Arab Novel." Commonwealth Essays and Studies, vol. 39, no. 2, 2017, p. 27-37.

PORTER, Caroline. "What We Know that We Don't Know: Remapping American Literary Studies." American Literary History, vol. 6, no. 3, 1994, p. 467-526.

PRATT, Mary Louise. “Arts of the Contact Zone.” Profession, 1991, p. 33-40.

REED, Tiffany D. “Modern Middle Eastern Women and their Rising Impact on Society." University of Arkansas Student Journal, 2010, p. 1-39.

SARNOU, Dalal. "Narratives of Arab Anglophone Women and the Articulation of a Major Discourse in a Minor Literature." International Studies: Interdisciplinary Political and Cultural Journal, vol. 16 , no. 1,2014 , p. 65-81.

YASSIN-KASSAB, Robin. "I was terribly wrong." Writers Look Back at the Arab Spring Five Years On.” The Guardian. Jan. 23, 2016. www.theguardian.com/books/2016/jan/23/arab-spring-fiveyears-on-writers-look-back. Accessed 17 Nov. 2018.

\section{NOTES}

1. The concept of mestizaje-which means racial mixture-is not only of interest to Latin Americans and Latin Americanists; in the USA, Europe and even postcolonial countries, increasing attention has been paid to processes of racial and cultural mixture, usually referred to by a series of different terms such as hybridity, syncretism, métissage, mélange and creolization -all, or some, of which may be related to other concepts, such as diaspora, which evoke the kinds of migrations and movements that lead to mixture. 


\section{ABSTRACTS}

Anglophone Arab writings have come of age after years of ethnic, religious and gender-based invisibility. This literature has carved out a niche for itself as a literature of minority, of womanhood and of borderlands. Recent theorizations on borderland zone(s) have endeavored to understand journeys of displacement and dislocation that immigrants may experience. The present paper offers an investigation of how the border zone, be it geographical or psychological, is fictionalized in Arab Anglophone women narratives. The novel of the Arab American Mohja Kahf, The Girl in the Tangerine Scarf (2006), highlights the borderland zone occupied by Arabs in the diaspora and represented by Khadra, the novel's protagonist. Kahf's novel serves here as a case study that shows how women characters have to negotiate their Arabness, Americanness and Islamness. The question is how.

Après être restée invisible pendant des années pour des raisons religieuses, ethniques, ou liées au genre, la littérature arabe anglophone connaît un essor remarquable. Elle s'affiche sous différents labels: écrits de femmes, littérature des minorités, littérature des frontières. Récemment, la théorisation des zones-frontières, a permis de mieux comprendre l'expérience du déplacement qui est celle des immigrants. Cet essai s'intéresse aux modes de fictionalisation de cette zone-frontière, qu'elle soit géographique ou psychologique, dans les récits de femmes arabes anglophones. Le roman de l'écrivaine arabe américaine Mohja Kahf, The Girl in the Tangerine Scarf (2006), est pris ici comme un cas d'étude qui met au jour la zone-frontière occupée par les Arabes de la diaspora, une zone représentée dans le texte par Khadra, la protagoniste principale. Le roman peut être lu comme une tentative de dépeindre la façon dont les personnages féminins sont tenus de négocier entre plusieurs identités: arabe, américaine, musulmane.

\section{INDEX}

Subjects: Hors-thème

Keywords: borderlands, Anglophone Arab writings, dislocation, Arab Diaspora

Mots-clés: espaces frontaliers, écrits arabes anglophones, dislocation, diaspora arabe

\section{AUTHOR}

DALAL SARNOU

Mostaganem University, Algeria 